\title{
Electronic nicotine delivery systems: overheating, fires and explosions
}

\author{
Susan F Rudy, ${ }^{1}$ Elizabeth L Durmowicz ${ }^{2}$
}

\begin{abstract}
- Additional material is published online only. To view please visit the journal online (http://dx.doi.org/10.1136/ tobaccocontrol-2015-052626).

${ }^{1}$ Office of Science/Division of Individual Health Science/ Medical Branch, United States Food \& Drug Administration/ Center for Tobacco Products, Silver Spring, Maryland, USA ${ }^{2}$ Office of Science/Division of Individual Health Science, FDA/ Center for Tobacco Products, Silver Spring, Maryland, USA
\end{abstract}

\section{Correspondence to} Susan F Rudy, Office of Science/Division of Individual Health Science/Medical Branch, USA Food \& Drug

Administration/Center for

Tobacco Products, Bldg.

75/Rm. 5464W, 10903

New Hampshire Ave., Silver Spring, MD 20993-0002, USA; Susan.rudy@fda.hhs.gov

Received 3 August 2015 Accepted 10 February 2016 Published Online First 9 March 2016

\section{SLinked}

- http://dx.doi.org/10.1136/ tobaccocontrol-2016-052985

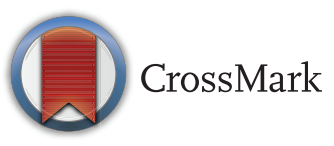

To cite: Rudy SF, Durmowicz EL. Tob Control 2017;26:10-18.

\section{ABSTRACT}

Background Electronic nicotine delivery system (ENDS)associated overheating, fire or explosion (OH/F/EXP) events have occurred since at least 2009.

Objective To identify the number and nature of ENDS OH/F/EXP events in the USA.

Methods Center for Tobacco Products (CTP) scientists searched for event reports among five US federal agencies, scientific literature and media outlets.

Findings 100 reference sources identified 92 OH/F/EXP events in the USA, of which $45(49 \%)$ injured 47 people, and $67(73 \%)$ involved property damage beyond the product. Events were identified in media outlets $(n=50 ; 54 \%)$ and reported to four agencies $(n=42$; $46 \%)$. The report rate peaked at an average of six reports per month in late 2013 with a smaller peak of three to four reports per month in the second quarter of 2015. All reports were incomplete and events exhibited variability. International events in three countries are mentioned, and international responses to events are summarised.

Conclusions The scope, causes and trajectory of ENDS $\mathrm{OH} / \mathrm{F} / \mathrm{EXP}$ events remain incompletely defined. Some events have resulted in life-threatening injury, permanent disfigurement or disability, and major property damage, suggesting the need for ongoing surveillance and risk mitigation. More comprehensive reporting could assist future analyses and may help to identify root causes and contributors to the OH/F/EXP events.

\section{BACKGROUND}

The US Food and Drug Administration (FDA), Center for Tobacco Products (CTP) began to receive voluntary reports of electronic nicotine delivery system (ENDS)-associated overheating, fire or explosion ( $\mathrm{OH} / \mathrm{F} / \mathrm{EXP})$ events in 2011 , and began to identify these events in media reports in 2012. In 2014, a US firefighter sent the FDA a number of media stories of e-cigarette F/EXP events along with his conclusion, 'A significant risk of death and/or serious injury exists. Immediate action is needed.' (United States Department of Health and Human Services, Food and Drug Administration, Center for Tobacco Products. Safety Reporting Portal. Report of City Fire Department Deputy Fire Marshal from California to FDA. Report date 8 May 2014. (Unpublished data)) In the same year, following an airline incident, a US firefighter wrote to the Consumer Product Safety Commission (CPSC) stating, "I am very concerned that these heat generating devices can be turned on through normal handling of luggage, causing a fire at any moment. If this fire had started in the cargo luggage area and was undetected while the plane was in flight a major tragedy could have occurred...It is apparent that if these e-cigarettes could start a fire in the skies, they may also be able to start fires in other settings, such as homes and businesses." (United States Consumer Product Safety Commission. Letter from Fire Marshal to CPSC Chairman re: E-cigarette Airport Luggage Fire. Letter date 15 Oct 2014. Incident date 9 Aug 2014. (Unpublished data)) Indeed, ENDS use has been documented in many settings that put users and non-users at risk for injury if the ENDS were to explode or catch fire, including medical settings, ${ }^{1-3}$ schools, ${ }^{45}$ multiunit housing, ${ }^{6-8}$ workplaces, restaurants and bars, ${ }^{9-11}$ jails, ${ }^{12}$ while driving, ${ }^{13}$ and on public transit systems, ${ }^{14}$ including an airborne passenger plane. ${ }^{15}$ The FDA/CTP has proposed to regulate ENDS as tobacco products for the protection of public health; ${ }^{16}$ hence, CTP explored the number and nature of $\mathrm{OH} / \mathrm{F} / \mathrm{EXP}$ events to evaluate their public health impact and to inform any potential future regulatory action.

\section{METHODS}

In 2012, CTP scientists launched an exploratory search among US federal agencies, the scientific literature and news media outlets to identify ENDS $\mathrm{OH} / \mathrm{F} / \mathrm{EXP}$ events, with results herein concluding 30 September 2015. Database search terms employed singular, plural, synonyms and other derivatives for ENDS products and their parts, and included event-related and injury-related terms, customised for the coded versus narrative data or syntax relevant to each database. The search terms evolved with our knowledge of products, events and the consumer vernacular. Online supplementary table S1 details the search strategy.

Five US federal agencies received relevant reports: the FDA, the Federal Aviation Administration (FAA), ${ }^{17}$ the CPSC, ${ }^{18}$ the US Coast Guard (USCG) ${ }^{19}$ and the US Fire Administration (USFA). ${ }^{20}$ Our knowledge of US federal agency jurisdictional authorities and interagency communications led us to identify these five agencies. The USFA receives firefighter-reported data about fire incidents. However, we utilised the USFA's publicly posted analysis of 25 media events to glean their perspective because they state that their National Fire Incident Reporting System (NFIRS) did not "...collect information... specific enough to provide accurate analysis of the frequency or impact of e-cigarette fires." 21

Reports were reviewed by at least two staff scientists who consulted other experts as needed. Minimum inclusion criteria were for a plausible event occurring in the USA involving an ENDS product or part. We excluded events originating 
from drills or exercises and battery incidents that did not identify the device intended for use with the battery. We manually reviewed event date and location, description and personally identifiable information (when available), to identify duplicate and follow-up reports in each incoming report batch, and then reviewed this data retrospectively for the entire set. The coauthors did not contact injured parties, investigators, media outlets or reporters to obtain additional or clarifying information.

\section{FINDINGS}

\section{Overview of ENDS OH/F/EXP Events in the US}

Scientists identified 92 discrete $\mathrm{OH} / \mathrm{F} / \mathrm{EXP}$ events reported in the USA (table 1). Forty-five reports (49\%) described injury of 47 people. Sixty-seven reports (73\%) described property damage beyond the product. FDA/CTP authors briefly had described 21 events previously. ${ }^{22-24}{ }^{i}$ The scientific literature yielded no additional events. Fifty events ${ }^{25-80}$ were identified from media outlets and 42 from reports to four US Federal government agencies by consumers/concerned citizens $(n=24)$, healthcare professionals $(\mathrm{n}=7)$, air transportation industry workers $(n=6)$ and fire fighters $(n=5)$ (United States Consumer Product Safety Commission. Letter from Fire Marshal to CPSC Chairman re: E-cigarette Airport Luggage Fire. Letter date 15 Oct 2014. Incident date 9 Aug 2014. (Unpublished data)); United States Department of Transportation, Federal Aviation Administration, Office of Security and Hazardous Materials Safety. National Aeronautics and Space Administration Aviation Safety Reporting System Telecon. Report 1263077. Report date 9 Jul 2015. (Unpublished data); United States Department of Health and Human Services, Food and Drug Administration, Center for Tobacco Products. Personal Communication from Fire Marshal to CTP Tobacco Product Surveillance Team. Event date 3 Nov 2013. Report date 12 Nov 2013. (Unpublished data); United States Department of Health and Human Services, Food and Drug Administration, Center for Tobacco Products. Safety Reporting Portal. Problem start date 26 Mar 2014. Report date 26 Mar 2014. (Unpublished data); United States Department of Health and Human Services, Food and Drug Administration, Center for Tobacco Products. Personal Communication from Concerned Citizen to CTP Ombudsman. Event date not reported. Report date 30 Apr 2014. (Unpublished data); United States Department of Health and Human Services, Food and Drug Administration, Center for Tobacco Products. Safety Reporting Portal. Problem start date 7 Aug 2014. Report date 7 Aug 2014. (Unpublished data); United States Department of Health and Human Services, Food and Drug Administration, Center for Tobacco Products. MedWatch. Event date 14 Apr 2015. Report date 17 Apr 2015. (Unpublished data); United States Department of Health and Human Services, Food and Drug Administration, Center for Tobacco Products. Safety Reporting Portal. Problem start date 19 Jun 2015. Report date 20 Jun 2015. (Unpublished data); United States Consumer Product Safety Commission. SaferProducts.gov Report. Incident date 29 Mar 2013. Report date 1 Apr 2013. (Unpublished data); United States Consumer Product Safety Commission. SaferProducts.gov Report. Incident date 18 Sep 2013. Report date 14 Oct 2013. (Unpublished data); United States Consumer Product Safety Commission.

${ }^{\mathrm{i}} \mathrm{Chen}^{22}$ described one; Yang et $a l^{23}$ described 19, including Chen's; Durmowicz $e t \mathrm{al}^{24}$ described three, including one of Yang et al's.
SaferProducts.gov Report. Incident date 25 Nov 2013. Report date 24 Mar 2014. (Unpublished data); United States Consumer Product Safety Commission. SaferProducts.gov Report. Incident date 20 Dec 2013. Report date 14 Apr 2014. (Unpublished data); United States Consumer Product Safety Commission. Hospital report to CPSC. Unique ID 131254591. Treatment date 24 Dec 2013 (Unpublished data); United States Consumer Product Safety Commission. SaferProducts.gov Report. Incident date 9 Jan 2014. Report date 14 Jan 2014. (Unpublished data); United States Consumer Product Safety Commission. SaferProducts.gov Report. Incident date 15 Jan 2014. Report date 20 Feb 2014. (Unpublished data); United States Consumer Product Safety Commission. SaferProducts.gov Report. Incident date 15 Nov 2013. Report date 20 Feb 2014. (Unpublished data); United States Consumer Product Safety Commission. SaferProducts.gov Report. Incident date 25 Jan 2014. Report date 27 Feb 2014. (Unpublished data); United States Consumer Product Safety Commission. SaferProducts.gov Report. Incident date 26 Jan 2014. Report date 28 Jan 2014. (Unpublished data); United States Consumer Product Safety Commission. SaferProducts.gov Report. Incident date 24 Feb 2014. Report date 25 Feb 2014. (Unpublished data); United States Consumer Product Safety Commission. SaferProducts.gov Report. Incident date 28 Feb 2014. Report date 28 Feb 2014. (Unpublished data); United States Consumer Product Safety Commission. SaferProducts.gov Report. Incident date 21 Mar 2014. Report date 24 Mar 2014. (Unpublished data); United States Consumer Product Safety Commission. SaferProducts.gov Report. Incident date 20 Apr 2014. Report date 29 Apr 2014. (Unpublished data); United States Consumer Product Safety Commission. SaferProducts.gov Report. Incident date 6 Aug 2014. Report date 12 Aug 2014. (Unpublished data); United States Consumer Product Safety Commission. SaferProducts.gov Report. Incident date 22 Apr 2015. Report date 5 Jun 2015. (Unpublished data); United States Consumer Product Safety Commission. SaferProducts.gov Report. Incident date 9 May 2015. Report date 9 May 2015. (Unpublished data); United States Consumer Product Safety Commission. SaferProducts.gov Report. Incident date 9 Jun 2015. Report date 11 Jun 2015. (Unpublished data); United States Consumer Product Safety Commission. SaferProducts.gov Report. Incident date 12 Jul 2015. Report date 24 Jul 2015. (Unpublished data); United States Consumer Product Safety Commission. SaferProducts.gov Report. Incident date 21 Jul 2015. Report date 23 Jul 2015. (Unpublished data)). ${ }^{81-97}$ The report rate peaked at an average of six reports per month in late 2013 with a smaller peak of three to four events per month in the second quarter of 2015 (figure 1). Reports to the government and the media are qualitatively similar in themes and extent of details, and so are discussed as one data set. Case summaries appear in online supplementary table S2.

\section{Summary of ENDS OH/F/EXP Events in the US}

The 47 injured comprise 34 users, 5 non-users and 8 of unclear user status. Injuries overall included chemical $(n=4)$ and thermal burns $(n=33)$, smoke inhalation $(n=4)$, fractured neck vertebrae $(n=2)$, fractured palate and finger $(n=1)$, loss, displacement or damage of one or more teeth $(n=3)$, lacerations $(\mathrm{n}=5)$, bruising $(\mathrm{n}=1)$, psychological distress $(\mathrm{n}=3)$, sensory disturbances $(n=3)$, nicotine overdose $(n=1)$ and oral discolorations $(n=1)$. Treatments overall ranged from first aid $(n=5)$ to hospitalisation for burn unit care $(\mathrm{n}=7)$ or surgical foreign body removal $(\mathrm{n}=1)$. Permanent effects $(\mathrm{n}=5$ users $)$ involved 
Table 1 US ENDS overheating/fire/explosion events by primary report recipient and year

\begin{tabular}{|c|c|c|c|c|c|c|}
\hline Calendar year & Number of FAA & Number of FDA & Number of Media & Number of CPSC & Number of USCG & Total number of US reports \\
\hline 2009 & 1 & 0 & 0 & 0 & 0 & 1 \\
\hline 2010 & 0 & 0 & 0 & 0 & 0 & 0 \\
\hline 2011 & 0 & 1 & 0 & 0 & 0 & 1 \\
\hline 2012 & 0 & 1 & 4 & 0 & 0 & 5 \\
\hline 2013 & 0 & 5 & 24 & 7 & 0 & 36 \\
\hline 2014 & 2 & 4 & 10 & 9 & 0 & 25 \\
\hline January 2015-September 2015 & 3 & 2 & 12 & ${ }^{*} 5$ & 2 & 24 \\
\hline Total & 6 & 13 & 50 & 21 & 2 & 92 \\
\hline \multicolumn{7}{|c|}{$\begin{array}{l}\text { CPSC, USA Consumer Product Safety Commission; ENDS, electronic nicotine delivery system; FAA, USA Department of Transportation/Federal Aviation Administration; FDA, USA } \\
\text { Department of Health \& Human Services/Food \& Drug Administration; USCG, USA Coast Guard/National Response Center. } \\
\text { The Primary Report Recipient represents the initial entity that received the report. For events reported to more than one entity, only the initial recipient is counted herein. } \\
\text { *Events reported by hospitals to CPSC were not yet available for } 2015 . \\
\text { Tallies are for dates available from the primary report recipients as follows: } \\
\text { FAA: date, not otherwise specified-based on one reliable corroborating reference (USA Consumer Product Safety Commission. Letter from Fire Marshal to CPSC Chairman re: } \\
\text { E-cigarette Airport Luggage Fire. Letter date } 15 \text { Oct } 2014 \text {. Incident date } 9 \text { Aug 2014. (Unpublished data)), five appear to be incident dates, one is a report date (USA Department of } \\
\text { Transportation, Federal Aviation Administration, Office of Security and Hazardous Materials Safety. National Aeronautics and Space Administration Aviation Safety Reporting System } \\
\text { Telecon. Report } 1263077 \text {. Report date } 9 \text { Jul 2015. (Unpublished data)). } \\
\text { FDA: event date or problem start date when available; otherwise the report date. } \\
\text { - Media: exact or approximate event date when available; otherwise the date the story was first published. } \\
\text { CPSC: incident date when available; otherwise treatment date. } \\
\text { - USCG: incident date. }\end{array}$} \\
\hline
\end{tabular}

disfigurement and disability. Non-user injuries ${ }^{\mathrm{ii}}$ included minor hand burns $(n=2)$, multiple burns $(n=1$ toddler) and hospitalisation for smoke inhalation $(n=3)$ or burns $(n=2)$. Two events involved youth of unknown user status: a 17-year-old sustained hand lacerations from product explosion, and two high school students 'messing with' an e-cigarette were uninjured from explosion.

Reports claimed property damage that ranged from minimal to US\$100 000 and 'loss of use of home'. Indoor settings were predominant $(\mathrm{n}=57(62 \%)$; residential $=46)$. OH/F/EXP events occurred during charging $(n=44(48 \%)$; residential=32), when handling after charging $(n=4)$, while inhaling or between puffs $(n=20 ; 22 \%)$, while holding $(n=3)$ or wearing the product in a pocket $(n=4)$, during transport $(n=5)$ and in storage $(n=4)$. Of eight events in automobiles, five were explosions in occupied or moving cars. Five passenger air-transportation events involved fire in a checked bag in an airport, fire in a checked and loaded bag before take-off, and baggage emissions on scheduled landing consisting of smoke $(n=1)$ or 'acid' $(n=1)$ from carry-on bags and smoke from a checked bag as it was being offloaded. There were two associated airoplane evacuations. Three commercial transportation events involved one fire in stowed air cargo on scheduled landing and fires in two ground sort centers -one after international air shipment. Other public settings for events were multiunit housing $(n=5)$, workplaces $(n=4)$, medical settings $(n=3$; two near medcal oxygen), bars or restaurants $(n=2)$ and a school.

Events involved a range of products at varied points in their lifespan. Most were e-cigarettes or parts; one was a 'pipe-shaped device' and another was a 'cigar-sized device'. Four events involved disposable e-cigarettes: two overheated and one exploded during use, and one exploded as its original package was opened. Fifty-five events (60\%) involved products described as rechargeable or placed on charge. Partially-identified batteries were 'lithium ion' $(n=7)$ 'lithium' rechargeable $(n=4$; including one 'Ultrafire protected'), 'lithium' $(n=5)$, 'lithium metal' $(n=2)$, 'nickel cadmium' $(n=1)$ and other $(n=8)$. Incomplete

${ }^{\mathrm{ii}}$ Three were earlier described by Durmowicz et al. ${ }^{24}$ charger/power source descriptors included: universal serial bus (USB)/computer $(\mathrm{n}=11), \mathrm{USB} /$ wall $(\mathrm{n}=2), \mathrm{USB} / \mathrm{car}(\mathrm{n}=1), \mathrm{USB}$ $(\mathrm{n}=1)$, wall $(\mathrm{n}=7)$, car $(\mathrm{n}=6)$ and cell phone $(\mathrm{n}=2)$. Events have occurred with the product-specific and substitution chargers. Time on charge before F/EXP events $(n=16)$ ranged from 'under 2 min' to $5 \mathrm{~h}$. One product exploded during its first charge. Product ages $(n=13)$ ranged from never used to 16 months.

Fire typically accompanied $(n=45)$, but twice preceded explosion. Seven reports plausibly described fire without explosion; seven plausibly described explosion without fire. Six reports described $\mathrm{OH}$ during use without progression to F/EXP, alleging failure of the activation button/battery to turn off $(n=2)$, and failure of the 'between-puff' shut-off mechanism in several devices $(n=1$ report). Reports further described $\mathrm{OH}$ during intermittent use over 1 week $(n=1)$ and 3 months $(n=1)$. Three additional $\mathrm{OH}$ reports described one product sitting idle, attended, on a counter for 20-30 min, and two in carry-on bags. Two $\mathrm{OH}$ reports described prompt actions taken to cool the device.

$\mathrm{OH} / \mathrm{F} / \mathrm{EXP}$ events have occurred both when following and in the absence of instructions. User actions that were possibly causative or contributory included: using a substitution charger, charging a non-rechargeable battery, using a recalled or incorrect battery and use near oxygen. Perceived harbingers $(n=18)$ were noises, odours, battery leakage, device motion, a flash or sparkling and smoke.

\section{RELEVANT LITERATURE FINDINGS}

\section{Summary of ENDS OH/F/EXP events outside of the USA}

The media have reported over $100 \mathrm{~F} / \mathrm{EXP}$ events in the UK, with an event rate of over one per week in late $2014 .{ }^{98}$ Listings of 19 UK cases show themes resembling those in US cases. ${ }^{99}$ Since late 2013, a Canadian fire with patient injury, ${ }^{100}$ two F/EXP-related deaths in the $\mathrm{UK}^{101-103}$ and the first reported Australian F/ $\mathrm{EXP}^{104}$ involved ENDS use around medical oxygen.

\section{Responses to OH/F/EXP events}

Consumer responses have included identical product replacement (thrice with a similar or worse event), obtaining a different ENDS, seeking information, warning others, requesting a 
Figure 1 ENDS overheating/fires/ explosions in the US, 2009-30 September 2015. ENDS, electronic nicotine delivery system.
*One 2014 event is not shown because it was reported by the media in March, 2015 as occuring "last year."

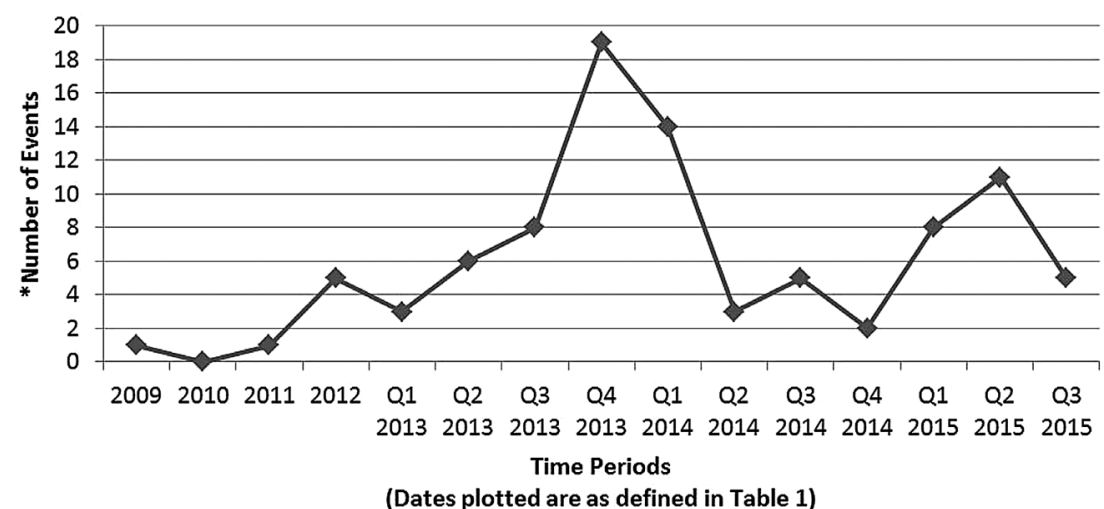

refund or compensation, filing lawsuits, returning to combusted cigarettes and pursuing cessation.

Retailer or manufacturer responses have included selling blast bags ${ }^{105}$ and safety storage or carrying boxes, retailer product quality checks, point-of-sale consumer education, apologising, collecting damaged product, offering refunds or replacements, inventory control, product recalls, ${ }^{106} 107$ blaming counterfeit products and product improvements in labelling and design.

Public health responses have included incident reporting guidance for US fire departments; ${ }^{108}$ Health Canada's Consumer Product Update warning of the fire risk of e-cigarette use around oxygen; ${ }^{109}$ and international aviation authority issuances toward banning e-cigarette use on commercial aircraft, ${ }^{110-113}$ requiring passengers to carry ENDS and spare batteries separately and exclusively in the cabin ${ }^{113} 117$ and banning ENDS product recharging aboard aircraft. ${ }^{113} 117$ Public posting of US events has occurred, ${ }^{17-19} 118$ and consumer safety advice has emerged from public health authorities and commercial entities. ${ }^{119-123}$

\section{DISCUSSION \\ Limitations}

Because of the well-known long-standing phenomenon of under-reporting for adverse events, as well as search methodology issues, data such as compiled herein cannot be used to calculate incidence or prevalence. Case reports may be inaccurate or incomplete and skewed towards reporting the more sensational events. Our analysis relied primarily on written text, as images were often unavailable or irrelevant. Event 'investigations' were inconsistent and incompletely detailed; some were challenged by lack of device identifiers and device damage. Thirty-four reports came from questionnaires structured for public safety surveillance, including four from the CTP Safety Reporting Portal's tobacco-specific questionnaire; ${ }^{124} 58$ reports came from unstructured sources. The varied data sources may have affected data reporting and analysis and may account for some of the observed event variability. Despite our best efforts, undetected duplicate cases may remain. Owing to the nature of the search and voluntary reporting to many sources, this compilation likely under-represents the true number of $\mathrm{OH} / \mathrm{F} / \mathrm{EXP}$ events.

\section{General discussion}

Although the actual number of ENDS $\mathrm{OH} / \mathrm{F} / \mathrm{EXP}$ events is unknown, rates appear to be low overall in relation to ENDS use rates. The event rate has fluctuated over time (figure 1) despite a steady annual increase in ENDS use in the USA. ${ }^{125}$ US adult 'ever use' of e-cigarettes has grown from $0.6 \%$ to $12.6 \%$ of the population between 2009 and $2014,{ }^{126}$ with $3.7 \%$ of US adults reporting e-cigarette use every day or some days in 2014. ${ }^{127}$ Decreased event rates may be related to voluntary product design and labelling improvements, consumer awareness and education or local and organisational bans on product use in various settings. ${ }^{9} 1114110111113128$ Increased event rates may be related to the increasing numbers of users with accompanying use or product presence in high-risk medical (United States Department of Health and Human Services, Food and Drug Administration, Center for Tobacco Products. Safety Reporting Portal. Problem start date 19 Jun 2015 . Report date 20 Jun 2015. (Unpublished data)) and air travel (United States Department of Transportation, Federal Aviation Administration, Office of Security and Hazardous Materials Safety. National Aeronautics and Space Administration Aviation Safety Reporting System Telecon. Report 1263077. Report date 9 Jul 2015. (Unpublished data)) $)^{85} 869697$ settings. The peaks and valleys in events between 2013 and 2015 (figure 1) do not correspond to our changes in search strategies. Drivers for fluctuations in reporting rates for tobacco product-associated adverse events are unknown.

In one explosion event reported to FDA (United States Department of Health and Human Services, Food and Drug Administration, Center for Tobacco Products. Personal Communication from Fire Marshal to CTP Tobacco Product Surveillance Team. Event date 3 Nov 2013. Report date 12 Nov 2013. (Unpublished data)), the Fire Marshal had identified the involved device as being among those recalled by a Chinese retailer due to a 'serious risk' of explosion during charging. ${ }^{106}$ To explore further for potential contributors to event rates we searched for current and historical ENDS product recalls in the scientific, business and consumer literature and in USA ${ }^{129}$ and global ${ }^{107}$ public product recall repositories, as detailed in online supplementary table S1. No recalls were found in the US repository, while the global repository had posted nine relevant recalls in English between 2012 and 2015. The recalls were for 'serious' electrical hazards of e-cigarettes or their electrical parts involving four European countries. Only one of the global recalls identified how many incidents had occurred $(n=1)$, and none provided data on how many products had been sold or were being recalled. Identified hazards included electric shock, fire or burns related to inadequate insulation of the charger, lack of a cut-off to avoid overcharging, insufficient clearance/creepage distances between the primary and secondary windings of the power supply, tip overheating while charging, insufficient internal connections and failure to comply with four European 
electrical product standards. ${ }^{130-133}$ Recall actions involved withdrawing the product from the market $(n=3)$, recalling the product from end users $(n=2)$ or both $(n=4)$. It is unclear if these recalls may have affected the US market. Seven of the recalls occurred in April-November, 2014, corresponding directly to a time of a precipitous decline followed by a low-level of $\mathrm{OH} / \mathrm{F} / \mathrm{EXP}$ events in the USA (figure 1). Searching the events listed in online supplementary table S2 for involved products, we found three with similar product identifiers and relevant outcomes that predated two of the recalls by 4-6 months (United States Consumer Product Safety Commission. SaferProducts.gov Report. Incident date 25 Jan 2014. Report date 27 Feb 2014. (Unpublished data); United States Consumer Product Safety Commission. SaferProducts.gov Report. Incident date 26 Jan 2014. Report date 28 Jan 2014. (Unpublished data); United States Consumer Product Safety Commission. SaferProducts.gov Report. Incident date 24 Feb 2014. Report date 25 Feb 2014. (Unpublished data)).

The benefits and drawbacks of various battery types and their failure modes, as well as standards relevant to battery and electronic device safety and transportation, have been presented elsewhere by engineers and other experts in the private ${ }^{134}$ and government sectors internationally. ${ }^{116} 117135136$ Two published analyses specific to e-cigarettes suggest preventive and corrective actions. After analysing $25 \mathrm{~F} / \mathrm{EXP}$ news reports ${ }^{\mathrm{iii}}$ in which $80 \%$ of events occurred during charging, the USFA concluded that battery failure rates are low compared to e-cigarette sales, but are likely to increase with sales, unless offset by design improvements. The USFA recommends user education on safe charging practices, strong warnings and product design changes to eliminate USB electrical connections, and to include electrical protection circuits. ${ }^{137}$ CTP engineers' systematic review of 2004-2013 e-cigarette products/designs from a systematic search including literature $(n=14)$, patents $(n=16)$, conferences $(n=3)$ and websites $(\mathrm{n}=2)$, suggested that overcharge protection, thermal power cut-offs and internal overpressure relief mechanisms could mitigate some battery failures. ${ }^{138}$ Whether ENDS products present any novel failure modes remains to be determined.

ENDS products are largely unregulated in the USA. Although some states, localities and organisations have laws or policies restricting sales or use in certain locations, the application of available risk mitigation knowledge and standards in ENDS design, manufacture, sales and use is largely voluntary. US consumers expect safety and predictability in the use and performance of electronic products and to be warned of associated risks. This expectation is reflected by at least six US F/EXP events resulting in legal proceedings and another seven events in which users reported of absent or misleading instructions for use or absent warnings. In October 2015, a US jury awarded \$1.9 million to a woman who claimed physical and emotional 'scarring for life' related to a 2013 ENDS product explosion. The jury found the US distributor, wholesaler and retailer at fault for being 'involved in the distribution of a product that failed to conform to any kind of reasonable safety expectation-battery chargers should not explode-and failed to warn about known dangers. ${ }^{139}$

US consumers also are accustomed to the correction of product problems identified. For example, the largest-ever consumer electronics safety recall was for Dell computers in 2006,

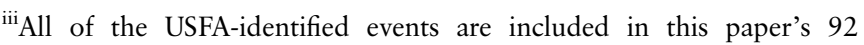
events. when 'several' $\mathrm{OH} / \mathrm{F}$ incidents resulted in the recall of 4.1 million laptops. ${ }^{140}$ In 2013, Hewlett Packard recalled 145000 laptop chargers after receiving nine reports of overheating and melting during use that included one minor burn injury and one minor property damage complaint. ${ }^{141}$ In 2015 , a singular $\mathrm{OH}$ event of a lithium-ion powered electronic credit card reader on a US airoplane, with no associated injuries, led the manufacturer to recall an undisclosed number of 'all similar models'. ${ }^{142-144}$ Accurate and complete sales data for specific brands and models of ENDS products in the USA are not available. However, it appears that the ENDS product sector may be lagging behind the mobile consumer electronics product sector in addressing this consumer safety risk.

\section{CONCLUSIONS}

Dispersed and rudimentary reporting in the USA has challenged efforts to identify and analyse ENDS OH/F/EXP events. Including a core information set in every report, such as fields shown in online supplementary table S2, may facilitate and improve future analyses. The use of complete product descriptors with standardised terminology for products and parts could further aid analyses. CTP's Safety Reporting Portal can accept complete event reports, including images and follow-up information. ${ }^{124}$

ENDS $\mathrm{OH} / \mathrm{F} / \mathrm{EXP}$ events are occurring internationally. The scope, causes and trajectory of events in the US remain incompletely defined. Despite increasing efforts by various authorities outside FDA to limit or control the settings in which ENDS may be used, in 2015 events have continued to occur in highrisk medical and air-transportation settings. The identified events vary in the involved products, parts, people, device-user interactions, environments, surrounding circumstances, and outcomes, which have included life-threatening injury, permanent disfigurement and disability, and major property damage. These findings suggest a need for ongoing surveillance, along with strategies to prevent and mitigate events such as: failure mode analyses; attention to device design; good manufacturing practices; educating consumers, industry and public health professionals about risk, prevention and event reporting; and continued regulatory efforts. Data on ENDS OH/F/EXP may inform clinical counselling, informed consent in clinical research, consumer best practices, product labelling, organisational and public health system policies and regulation.

\section{What this paper adds}

- This is the largest compilation of US electronic nicotine delivery system (ENDS) overheating/fire/explosion (OH/F/EXP) events analysed and published to date.

- The causes, numbers and trajectory of ENDS OH/F/EXP events remain incompletely defined.

- This limited data set provides information to support exploration of strategies to prevent or mitigate ENDS OH/F/ EXP events for the protection of public health.

Acknowledgements Daniel P. St. Laurent, RN, MS for technical assistance with manuscript preparation. Deborah Neveleff, MBA for editorial assistance with manuscript preparation. Gwendolyn Halford, MLS and Joyce Kitzmiller, MLS for assistance in setting up and conducting literature searches. Paul Aguilar, MPH; Sarah Lee, MPH; Tara Smith, Pharm D, M.S., CCRP; and Mary Jo Salerno, MPH, $\mathrm{CPH}$ for assistance with Google Alert searches and reference management. Nancy Chang, MD for limited assistance with case analysis. Ryan D. Foringer, engineering 
consultant. Baoguang Wang, MD, MPH for assistance with information on Consumer Product Safety Commission data sources and information shared by the CPSC. The Consumer Product Safety Commission (CPSC), Data Intake and Information Branch (EPDSI) for information sharing. The USA Department of Transportation, Federal Aviation Administration (FAA), Hazardous Materials Safety Office (HMSP) for assistance in locating the publicly posted FAA and USA Coast Guard National Response Center data and for information sharing. The USA Department of Homeland Security, Federal Emergency Management Agency, USA Fire Administration, National Fire Data Center for information about their related activities and data. Ii-Lun Chen, MD, Cathy L. Backinger, PhD, MPH, and Corinne Husten, MD, MPH for management-level manuscript review and revision.

Contributors SFR directed or conducted the literature and report searches, was the primary event analyst, drafted and revised the paper. BD was a secondary event analyst, reviewed and edited the paper.

Competing interests None declared.

Disclaimer This information is not a formal dissemination of information by FDA and does not represent Agency position or policy.

Provenance and peer review Not commissioned; externally peer reviewed.

Data sharing statement Reports posted to CTP's public Freedom of Information Act (FOIA) Electronic Reading Room may move (have a new web address) in the future. The reports can be located on the FDA public website http://www.fda.gov by searching the term "CTP FOIA Electronic Reading Room." Unpublished reports to the FDA can be acquired by submitting a FOIA request. Instructions are posted to http://www.fda.gov/Regulatorylnformation/FOl/HowtoMakeaFOIARequest/ ucm2007229.htm. FOIA requests should be submitted in writing to: Food and Drug Administration. Division of Freedom of Information. Office of the Executive Secretariat, OC. 5630 Fishers Lane, Room 1035, Rockville, MD 20857, Phone: 301 796 3900, FAX 301827 9267. Online FOIA Requests to the FDA can be submitted via http://www.accessdata.fda.gov/scripts/foi/FOIRequest/index.cfm. Unpublished reports to the CPSC can be acquired by submitting a FOIA request to: FOIA Requester Service Center, US Consumer Product Safety Commission, 4330 East West Highway, Room 820, Bethesda, MD 20814, Tel. 301-504-7923 and Fax. 301504-0127, E-mail: cpsc-foia@cpsc.gov, Or contact the CPSC FOIA Public Liaisons: Deborah Acosta, dacosta@cpsc.gov, Tel. 301-504-6821. Lynn Carter, Icarter@cpsc. gov, Tel. 301-504-6890. The latest guidelines on making a CPSC FOIA request are posted to http://www.cpsc.gov/en/Newsroom/FOIA/Make-a-FOIA-Request/. Unpublished reports to the FAA can be acquired by submitting a FOIA request online via: https://www.faa.gov/foia/email_foia/index.cfm?region=hq. For further information, contact: Federal Aviation Administration, Douglas Taylor, National Freedom of Information Act Staff, AFN-140, 800 Independence Avenue, SW, Washington, DC 20591, Phone: (202) 267-7799, Fax: (202) 267-6514.

\section{REFERENCES}

1 Keaveny P. Oxygen fireball horror as e-cigarette grandmother is blown up in hospital. Sun 14 April 2014. http://www.thesun.co.uk/sol/homepage/news/ 5567827/E-cigarette-gran-blown-up-in-hospital.html (accessed 5 Aug 2014).

2 E-cigarette charger catches fire at hospital. Worthing Herald 6 March 2014. http:// www.worthingherald.co.uk/news/local/e-cigarette-charger-catches-fire-at-hospital1-6096598 (accessed 4 Jun 2014).

3 Monroy AE, Hommel E, Smith ST, et al. Paryoxysmal atrial fibrillation following electronic cigarette use in an elderly woman. Clin Geriatr 2012;20:28-32.

4 Editorial: Vaping in boys' room? Could be a real issue. The Sanford Herald 22 April 2015. http://www.sanfordherald.com/opinion/x926854574/ EDITORIAL-Vaping-in-boys-room-Could-be-a-real-issue (accessed 1 May 2015).

5 McAteer O. School evacuated after e-cigarette explodes. Metro 15 October 2014. http://metro.co.uk/2014/10/15/ school-evacuated-after-e-cigarette-explodes-4907197/ (accessed 16 Apr 2015).

6 Rebecca SD. E-cigarette believed to have caused student flat fire. Nottingham Post 7 March 2014. http://www.nottinghampost.com/E-cigarette-believedcaused-student-flat/story-20780005-detail/story.html (accessed 7 Mar 2014).

7 Poole Parkstone Road flats evacuated after 'e-cigarette fire'. BBC News 19 February 2014. http://www.bbc.com/news/uk-england-dorset-26262633 (accessed 11 Aug 2014).

8 Boese C. Student housing discussing new smoking policies. Kansan 4 February 2015. http://www.kansan.com/news/student-housing-discussing-new-smokingpolicies/article_e1a445ba-acd2-11e4-b703-2f5fc46d76e2.html (accessed 12 Jun 2015)

9 Whitsel LP, Benowitz N, Bhatnagar A, et al. Guidance to employers on integrating e-cigarettes/electronic nicotine delivery systems into tobacco worksite policy. J Occup Environ Med 2015;57:334-43.

10 Video: E-cigarette explodes in barmaid's face after being put on iPad charger Metro 8 April 2014. http://metro.co.uk/2014/04/08/video-e-cigarette-explodes-inbarmaids-face-after-being-put-on-ipad-charger-4692238/ (accessed 30 Jul 2014).

11 Marynak K, Holmes CB, King BA, et al. State laws prohibiting sales to minors and indoor use of electronic nicotine delivery systems — United States, November 2014.
MMWR 2014;64:1145-50. http://www.cdc.gov/mmwr/preview/mmwrhtml/ mm6350a10.htm?s_cid=mm6350a10_w

12 Young-Wolff KC, Karan LD, Prochaska JJ. Electronic cigarettes in jails: a panacea or public health problem? JAMA Psychiatry 2015:72:103-4.

13 Fox L. Vaping and driving. Ecigarette Reviewed 14 March 2014. http:// ecigarettereviewed.com/vaping-and-driving-safety (accessed 12 Jun 2015).

14 Klein EG, Kennedy RD, Berman M. Tobacco control policies in outdoor areas of high volume American transit systems. J Community Health 2014;39: 660-7.

15 E-cigarette sparks in-flight emergency for BWI-bound plane. The Baltimore Sun 11 December 2014. http://www.baltimoresun.com/news/maryland/ bs-md-bwi-smoke-20141211-story.html (accessed 12 Dec 2014).

16 United States Department of Health and Human Services, Food and Drug Administration. Deeming tobacco products to be subject to the Federal Food, Drug, and Cosmetic Act, as amended by the Family Smoking Prevention and Tobacco Control Act. 21 CFR Parts 1100, 1140, and 1143. 25 Apr 2014. Federal Register 2014;79(80). http://www.fda.gov/TobaccoProducts/GuidanceCompliance Regulatorylnformation/ucm394909.htm (accessed 28 Jul 2015).

17 United States Department of Transportation, Federal Aviation Administration (FAA) Office of Security and Hazardous Materials Safety. Batteries \& Battery-powered Devices: Aviation cargo and passenger baggage incidents involving Smoke, Fire, Extreme heat or explosion. 30 June 2015. http://www.faa.gov/about/office_org/ headquarters_offices/ash/ash_programs/hazmat/aircarrier_info/media/battery_ incident_chart.pdf (accessed 30 Sep 2015).

18 United States Consumer Product Safety Commission (CPSC). National Electronic Injury Surveillance System (NEISS)—Archived Full NEISS Data by year. http://www. cpsc.gov/en/Research--Statistics/NEISS-Injury-Data/ (accessed 23 Oct 2015).

19 United States Coast Guard. National Response Center. http://www.nrc.uscg.mil/ (accessed 20 Oct 2015).

20 United States Department of Homeland Security, Federal Emergency Management Administration, United States Fire Administration. National Fire Incident Reporting System. http://www.usfa.fema.gov/data/nfirs/index.html (accessed 13 March 2015).

21 United States Department of Homeland Security, Federal Emergency Management Administration, United States Fire Administration (USFA). Electronic cigarette fires and explosions (p.3). Oct 2014. https://www.usfa.fema.gov/downloads/pdf/ publications/electronic_cigarettes.pdf (accessed 13 Mar 2015).

22 Chen I. Letter: FDA summary of adverse events on electronic cigarettes. Nicotine Tob Res 2013;15:615-16

23 Yang L, Rudy SF, Cheng JM, et al. Electronic cigarettes: incorporating human factors engineering into risk assessments. Tob Control 2014;23:ii47-53.

24 Durmowicz EL, Rudy SF, Chen I. Electronic cigarettes: analysis of FDA adverse experience reports in non-users. Tob Control 2016;25:242.

25 Hood JR. E-cigarette exploded in man's face, suit charges. Consumer Affairs 17 April 2012. https://www.consumeraffairs.com/news04/2012/04/ e-cigarette-exploded-in-mans-face-suit-charges.html (accessed 23 Apr 2015).

26 Are smokeless cigarettes safer? E-cig explodes in smoker's mouth. Los Angeles Times 16 February 2012. http://latimesblogs.latimes.com/nationnow/2012/02/ electronic-cigarette-explodes-mans-mouth.html (accessed 16 Feb 2012).

27 CBS News Staff. Electronic cigarette explodes in man's mouth, causes serious injuries. CBSNEWS 16 February 2012. http://www.cbsnews.com/news/ electronic-cigarette-explodes-in-mans-mouth-causes-serious-injuries/ (accessed 28 Mar 2014).

28 Electronic cigarette explodes in Muskogee woman's hand. Fox23.com 18 April 2012. http://www.fox23.com/mostpopular/story/Electronic-cigarette-explodesin-Muskogee-womans/ek2×6P6rvkyLu5cMrvGwVQ.cspx (accessed 12 Nov 2013). Later available only in video at http://www.fox23.com/videos/news/ electronic-cigarette-explodes-in-muskogee-womans/vCM9mM/ (accessed 18 Jun 2015)

29 Downing M. Sherman man's e-cigarette explodes while charging. News 12 KXII. com 16 July 2013. http://www.kxii.com/news/headlines/E-cigarette-explodes-inTexoma-mans-home-215771641.html (accessed 17 Jul 2013).

30 Romboy DSL. County man sues after e-cigarette explodes in his face. Deseret News 3 November 2014. http://www.deseretnews.com/article/print/865614645/ SL-County-man-sues-after-e-cigarette-explodes-in-his-face.html (accessed 16 Apr 2015).

31 Corona couple sues after e-cigarette battery explodes in car. CBS Los Angeles 11 July 2013. http://losangeles.cbslocal.com/2013/07/11/corona-couple-sues-after-ecigarette-battery-explodes-in-car/ (accessed 22 Apr 2015).

32 Police: 'Explosion' at apartment complex came from e-cigarette. Koco.com 16 April 2013. http://www.koco.com/news/oklahomanews/okc/Police-Explosion-atapartment-complex-came-from-e-cigarette/19768650 (accessed 5 Jun 2015).

33 Reiser L. Lighting up: E-cigarette charger sparks car fire in AZ. CBS5. KPHO Broadcasting Corporation. 24 April 2013, updated 9 May 2013. http://www.ksla. com/story/22071692/lighting-up-e-cigarette-charger-sparks-car-fier-in-az (accessed 20 May 2013).

34 Tulsa man's e-cigarette catches fire while charging. NewsOn6 7 June 2013. http:/l www.newson6.com/story/22536957/tulsa-mans-e-cig-catches-fire-while-charging (accessed 22 Apr 2015). 
35 Navarrete K. E-cigarette nearly sparks fire at Phoenix apartment. CBS 5-KPHO Broadcasting Corp 27 August 2013, updated 11 Sep 2013. http://www.kpho.com/ story/23273275/e-cigarette-nearly-sparks-fire-at-phoenix-apartment (accessed 31 Jul 2014).

36 Chaney J. E-cigarette explodes and sparks small fire. KFOR.com 1 August 2013. http://kfor.com/2013/08/01/e-cigarette-explodes-and-sparks-small-fire/ (accessed 31 Jul 2014).

37 Proulx S. Fire Marshal: Charging electronic cigarette sparked fire. WBNG 2 September 2013. http://www.wbng.com/internal?st=print\&id=222081441\&path=/ news/local\# (accessed 23 Apr 2015).

38 Strickland J. Woman says E-cigarette exploded, shot flames 4 feet across living room. WSBTV 2 September 2013. http://www.wsbtv.com/news/news/local/ woman-says-e-cigarette-exploded-shot-flames-4-feet/nZkCX/ (accessed $22 \mathrm{Apr}$ 2015).

39 Elizabeth Wilkowski, Atlanta woman, claims e-cigarette explosions almost destroyed her home. The Huffington Post 4 September 2013. http://www. huffingtonpost.com/2013/09/04/elizabeth-wilkowski-e-cigarette-explosion_n_ 3865233.html (accessed 5 Jun 2015).

40 McFall M. Exploding e-cigarette set toddler's clothes afire, Utah fire marshal says. The Salt Lake Tribune 24 September 2013. http://www.sltrib.com/sltrib/news/ 56916022-78/fire-schofield-cigarette-marshal.html.csp (accessed 1 Oct 2013).

41 Wasserman S. Minnesota man's e-cig explodes while charging. KMSP-TV 1 October 2013, updated 2 October 2013. http://www.myfoxtwincities.com/story/ 23584719/minnesota-e-cig-explosion-charging (accessed 15 Apr 2014).

42 Christie J. No smoke, but lots of fire! Another e-cigarette explosion smolders home as officials warn you don't need to 'light up' to be in danger. Mail Online 3 October 2013. http://www.dailymail.co.uk/news/article-2442715/ E-cigarette-explosion-causes-Wisconsin-home.html (accessed 11 Oct 2013).

43 McCurdy A. Electronic cigarette explodes, catches curtains on fire. NWFDailynews. com 7 October 2013. http://www.nwfdailynews.com/local/electronic-cigaretteexplodes-catches-curtains-on-fire-1.214335 (accessed 23 Apr 15)

44 Thomas R. Phoenix FD. Faulty e-cigarette likely to blame for fire that injured Vietnam vet. CBS5 KPHO Broadcasting Corp 25 October 2013, updated 8 November 2013. http://www.kptv.com/story/23785774/phoenix-fd (accessed 23 Apr 2015).

45 Gilger L. Phoenix Fire Department Officials warn electronic cigarette users about fire danger. Scripps Media Inc 31 December 2013. http://www.abc15.com/dpp/ news/local_news/investigations/phoenix-fire-department-officials-warnelectronic-cigarette-users-about-fire-danger (accessed 2 Jan 2014).

46 Gilger L, Tomasch M, Alter $M$, et al. Vaping, the latest phenomenon to hit the cigarette industry, is spurring health concerns. Knoxville News Sentinel 2 January 2014. http://www.knoxnews.com/news/2014/jan/02/vaping-latest-phenomenonhit-cigarette-industry-sp/?print=1 (accessed 3 Jan 2014).

47 Shukhnov K. E-cigarette blamed for house fire in Idaho, electronic cigarette battery overcharged and exploded. WPTV 5 November 2013. http://www.wptv.com/news/ local-news/water-cooler/e-cigarette-blamed-for-house-fire-in-idaho-electroniccigarette-battery-overcharged-and-exploded\#ixzz2jp8kYxzd (accessed 31 Jul 2014).

48 Trent W. Exploding electronic cigarette blamed for fire. Azfamily.com 11 November 2013. http://www.azfamily.com/news/consumer/Exploding-electronic-cigaretteblamed-for-fire-231499581.htmlhttp://www.azfamily.com/news/consumer/ Exploding-electronic-cigarette-blamed-for-fire-231499581.html (accessed 12 Nov 2013).

49 Gatton DD. E-cig explodes, damaging truck. KVAL.com 11 November 2013. http:// www.kval.com/news/local/E-cig-explodes-damaging-truck-231482791.html? tab=video\&c=y (accessed 22 Apr 2015)

50 Craig K. Warren woman says electronic cigarettte caused small explosion and fire. $A B C 7$, WXYZ Detroit 14 November 2013. http://www.wxyz.com/news/warrenwoman-says-electronic-cigarette-caused-small-explosion-and-fire (accessed 23 Apr 2015).

51 E-cigarette blamed for mattress fire. KRDO.com 28 November 2013. http://www.krdo. com/news/ecigarette-blamed-for-mattress-fire/23206306 (accessed 23 Apr 2015).

52 DeMasters T. E-cigarette explodes while charging. Fox13 Salt Lake City 9 December 2013. http://www.fox13now.com/2013/12/09/3-cigarette-explodeswhile-charging/ (accessed 13 Dec 2013).

53 Kurwicki H. Only on 3: Man says e-cig caused temporary blindness. WWAY TV3 ABC.com 12 December 2013. http://www.wwaytv3.com/2013/12/12/ only-3-man-says-e-cig-caused-temporary-blindness (accessed 13 Dec 2013).

54 Thomas C. Man injured after e-cig blows up. The Daily News-Jacksonville, NC 11 January 2014. http://www.jdnews.com/news/local/man-injured-after-e-cigblows-up-1.260632 (accessed 23 Apr 2015).

55 Landis M, Foster R. Man experiences 'explosive' consequence from using e-cigarette. KY3 News 23 January 2014. http://www.ky3.com/news/local/ man-expereinces-explosive-consequence-from-using-electronic-cigarette/21048998 24083270? view=print (accessed 23 Apr 2015).

56 Sanchez V. Call 12: E-cigarettes pose risk of explosion. The Arizona Republic. Gannett Co. 8 February 2014. http://www.azcentral.com/business/call12foraction/ articles/20140208e-cigarettes-pose-risk-explosion-call12.html?nclick_check=1 (accessed 20 Feb 2014).

57 KGW Staff. E-cigarette batteries caused 2 Medford fires. KGW.com Portland. 3 March 2014. http://www.kgw.com/news/E-cigarette-batteries-caused-2-Medfordfires--248238801.html\# (accessed 28 Mar 2014).

58 The Associated Press. Fire marshal: E-cigarette batteries cause fires in Medford. KATU.com 3 March 2014. http://www.katu.com/news/local/Fire-marshal-Ecigarette-batteries-cause-fires-in-Medford-248274331.html (accessed 23 Apr 2015).

59 Mulder JT. Syracuse hospital bans e-cigarettes after patient on oxygen catches fire while using one. Syracuse Media Group 22 April 2014. http://www.syracuse.com/ news/index.ssf/2014/04/syracuse_hospital_bans_e-cigarettes_after_patient_ catches_fire_while_using_one.html\#incart_river_default (accessed 5 Aug 2014).

60 Cigarette charger blamed for fire. Lompoc Record 9 May 2014. http:// lompocrecord.com/news/local/cigarette-charger-blamed-for-fire/article_ 08a8532c-d745-11e3-8194-001a4bcf887a.html (accessed 19 Jun 2015).

61 E-cigarette charger sparks OKC home fire; woman burned. News9.com 3 July 2014. http://www.news9.com/story/25932561/e-cigarette-charger-sparksokc-home-fire-woman-burned (accessed 30 Mar 2015).

62 Mendoza J. Fire at Honolulu apartment blamed on e-cigarette. Hawaii News Now 29 September 2014. http://www.hawaiinewsnow.com/story/26659072/ explosion-at-honolulu-apartment-blamed-on-e-cigarette (accessed 15 Apr 2015).

63 Chen N. E-cigarette explosion caused Tacoma house fire. Cox Media Group 12 November 2014. http://www.kirotv.com/news/news/1-taken-hospital-tacomahouse-fire/nh5Tq/ (accessed 16 Apr 2015).

64 Bechtel N. E-cigarette causes home fire. Marion Star. Gannett Co 17 December 2014. http://www.marionstar.com/story/news/local/2014/12/17/ cigarette-causes-home-fire/20542429/ (accessed 16 Apr 2015).

65 Baker MB. Smokin' hot: Man claims e-cig batteries sent sparks 'shooting from his crotch area'. Star-Telegram 11 March 2015. http://www.star-telegram.com/news/ local/community/arlington/article13493492.html (accessed 12 Mar 2015).

66 Corona M, Marcus E. Electronic cigarette blamed for Nev. High school gym explosion. USAToday Network 13 January 2014. http://www.usatoday.com/story/ news/nation-now/2015/01/13/electronic-cigarette-gym-explosion-nevada/ 21699097/ (accessed 16 Apr 2015).

67 Powell S. Oak Ridge woman says her e-cigarette exploded while charging. WVLT-TV 15 January 2015. http://www.local8now.com/home/headlines/ Oak-Ridge-womans-e-cigarette-blows-up-while-charging-288744041.html (accessed 16 Apr 2015).

68 Fox5 Digital Team. E-cigarette explodes in man's face. KSWB, Tribune Broadcasting Station 9 February 2015. http://fox5sandiego.com/2015/02/09/ e-cigarette-explodes-in-mans-face/ (accessed 17 Feb 2015).

69 Hernandez M. E-cigarettes may lead to explosions, fires. $A B C 7$ Eyewitness News Los Angeles, $A B C$ Inc 11 February 2015. http://abc7.com/news/ e-cigarettes-may-lead-to-explosions-fires/513968/ (accessed 21 Apr 2015).

70 Scripps Media, Inc. Man hurt when e-cigarette turns into mini-pipe bomb. WKBW Buffalo. The E.W. Scripps Co 12 March 2015. http://www.wkbw.com/ news/man-hurt-when-e-cigarette-turns-into-mini-pipe-bomb (accessed 21 Apr 2015)

71 13WHAM. How common are exploding e-cigs? ABC 16 March 2015. http:/l 13wham.com/news/features/top-stories/stories/how-common-explodingecigs-20982.shtml (accessed 17 Mar 2015).

72 Horvatits C. Firefighters: Gates e-cigarette explosion likely caused by battery issue. News10 WHEC Rochester. WHEC-TV, LLC 13 March 2015. http://www.whec.com/ news/stories/S3734487.shtml?cat=565 (accessed 21 Apr 2015).

73 Rocha V. L.A. Now: Exploding e-cigarette: Man burned; bed set on fire. Los Angeles Times 9 March 2015. http://touch.latimes.com/\#section/601/article/ p2p-83014846/ (accessed 10 Mar 2015).

74 Duranty A. OCFA: Man injured after e-cigarette explodes near his face in Santa Ana apartment. The Orange County Register 9 March 2015. http://www.ocregister. com/articles/fire-653537-concialdi-ocfa.html (accessed 21 Apr 2015).

75 Lodor S. Little Egg Harbor knows e-cigarettes can explode. Press of Atlantic City 28 April 2015. (http://www.pressofatlanticcity.com/news/breaking/ little-egg-harbor-knows-e-cigarettes-can-explode/article 6f7693d0-ed4b-11e4-b70f-a3cb9214b370.html (accessed 15 Jul 2015).

76 Boggs N. Facebook News Feed 22 May 2015. https://www.facebook.com/finestof. linestattoo/posts/479910565490879 (accessed 1 Jun 2015).

77 Dewberry D. Man burned when e-cigarette battery explodes in his pocket. NBCDFW.com 21 September 2015. http://www.nbcdfw.com/investigations/ Man-Burned-When-E-Cigarette-Battery-Explodes-in-His-Pocket-328575811.html (accessed 24 Sep 2015).

78 Austin man says e-cigarette battery exploded in his pocket. myfoxaustin.com 22 July 2015. http://myinforms.com/en/a/14830688-austin-man-says-e-cigarettebattery-exploded-in-his-pocket/ (accessed 23 Oct 2015).

79 Pan P. Exclusive: Man severely injured after eCigarette blows up in his face. Fox5DC 8 September 2015. http://www.fox5dc.com/news/national/17391566-story (accessed 23 Oct 2015). 
80 Wimbley R. Wyandotte man injured smoking exploding vape pen. Fox 2 News 3 August 2015. http://www.myfoxdetroit.com/story/29701028/wyandotte-maninjured-smoking-exploding-vape-pen (accessed 5 Aug 2015).

81 United States Department of Transportation, Federal Aviation Administration, Office of Security and Hazardous Materials Safety. Batteries \& Battery-Powered Devices: Aviation Cargo and Passenger Baggage Incidents Involving Smoke, Fire, Extreme Heat or Explosion. 30 June 2015. FedEx, Date 14 Aug 2009, p. 12. http://www. faa.gov/about/office_org/headquarters_offices/ash/ash_programs/hazmat/aircarrier_ info/media/battery_incident_chart.pdf (accessed 29 Sep 2015).

82 United States Department of Transportation, Federal Aviation Administration, Office of Security and Hazardous Materials Safety. Batteries \& Battery-Powered Devices: Aviation Cargo and Passenger Baggage Incidents Involving Smoke, Fire, Extreme Heat or Explosion. 30 June 2015. DHL, Date 25 Febuary 2014, p. 5. http://www. faa.gov/about/office_org/headquarters_offices/ash/ash_programs/hazmat/aircarrier_ info/media/battery_incident_chart.pdf (accessed 29 Sep 2015).

83 United States Department of Transportation, Federal Aviation Administration, Office of Security and Hazardous Materials Safety. Batteries \& Battery-Powered Devices: Aviation Cargo and Passenger Baggage Incidents Involving Smoke, Fire, Extreme Heat or Explosion. 30 June 2015. JetBlue, Date 9 August 2014, p. 4. http://www. faa.gov/about/office_org/headquarters_offices/ash/ash_programs/hazmat/aircarrier_ info/media/battery_incident_chart.pdf (accessed 29 Sep 2015).

84 Marcelo P. E-cigarette might have caused fire on plane, U.S. government urged to consider restrictions. Canada.com 18 August 2014. http://o.canada.com/travel/ e-cigarette-might-have-caused-fire-on-plane-u-s-government-urged-to-considerrestrictions (accessed 15 Apr 2015).

85 United States Department of Transportation, Federal Aviation Administration, Office of Security and Hazardous Materials Safety. Batteries \& Battery-Powered Devices: Aviation Cargo and Passenger Baggage Incidents Involving Smoke, Fire, Extreme Heat or Explosion. 30 June 2015. SkyWest, Date 4 January 2015, p. 3. http:/l www.faa.gov/about/office_org/headquarters_offices/ash/ash_programs/hazmat/ aircarrier_info/media/battery_incident_chart.pdf (accessed 29 Sep 2015).

86 United States Department of Transportation, Federal Aviation Administration, Office of Security and Hazardous Materials Safety. Batteries \& Battery-Powered Devices: Aviation Cargo and Passenger Baggage Incidents Involving Smoke, Fire, Extreme Heat or Explosion. 30 June 2015. Southwest, Date 10 June 2015, p.1. http:/l www.faa.gov/about/office_org/headquarters_offices/ash/ash_programs/hazmat/ aircarrier_info/media/battery_incident_chart.pdf (accessed 29 Sep 2015).

87 United States Department of Health and Human Services, Food and Drug Administration, Center for Tobacco Products. CTP FOIA Electronic Reading Room: Special Interest Topics -E-cigarette Adverse Events: Adverse Events 6/22/09 to 6/ 25/13 (p. 97). MedWatch. Event date 27 June 2011. Report date 27 June 2011. http://www.fda.gov/AboutFDA/CentersOffices/OfficeofMedicalProductsandTobacco/ AbouttheCenterforTobaccoProducts/ucm221165.htm (accessed 3 Jun 2015).

88 United States Department of Health and Human Services, Food and Drug Administration, Center for Tobacco Products. CTP FOIA Electronic Reading Room: Special Interest Topics - E-cigarette Adverse Events: Adverse Events 6/22/09 to 6/ 25/13 (p. 39). MedWatch. Event date 17 June 2012. Report date 7 July 2012. http://www.fda.gov/AboutFDA/CentersOffices/OfficeofMedicalProductsandTobacco/ AbouttheCenterforTobaccoProducts/ucm221165.htm (accessed 3 Jun 2015).

89 United States Department of Health and Human Services, Food and Drug Administration, Center for Tobacco Products. CTP FOIA Electronic Reading Room: Special Interest Topics-E-cigarette Adverse Events: Adverse Events 6/22/09 to 6/ 25/13 (p. 10). MedWatch. Event date 2 May 2013. Report date 15 May 2013. http://www.fda.gov/AboutFDA/CentersOffices/OfficeofMedicalProductsandTobacco/ AbouttheCenterforTobaccoProducts/ucm221165.htm (accessed 3 Jun 2015)

90 United States Department of Health and Human Services, Food and Drug Administration, Center for Tobacco Products. CTP FOIA Electronic Reading Room: Special Interest Topics - E-cigarette Adverse Events: Adverse Events 6/22/09 to 6/ 25/13 (p. 9). MedWatch. Event date 29 May 2013. Report date 29 May 2013. http://www.fda.gov/AboutFDA/CentersOffices/OfficeofMedicalProductsandTobacco/ AbouttheCenterforTobaccoProducts/ucm221165.htm (accessed 3 Jun 2015).

91 United States Department of Health and Human Services, Food and Drug Administration, Center for Tobacco Products. CTP FOIA Electronic Reading Room: Special Interest Topics - E-cigarette Adverse Events: Adverse Events 6/25/13 to 10/5/13 (p. 19). MedWatch. Event date 20 September 2013. Report date 24 September 2013. http://www.fda.gov/AboutFDA/CentersOffices/ OfficeofMedicalProductsandTobacco/AbouttheCenterforTobaccoProducts/ ucm221165.htm (accessed 3 Jun 2015).

92 Kulwicki MF. Child burned after e-cigarette explodes in car charger. Fox13. 21 September 2013. http://fox13now.com/2013/09/21/child-burned-after-e-cigaretteexplodes-in-car-charger/ (accessed 22 Apr 2015).

93 United States Department of Health and Human Services, Food and Drug Administration, Center for Tobacco Products. CTP FOIA Electronic Reading Room: Special Interest Topics-E-cigarette Adverse Events: Adverse Events 10/5/13 to 3/12/14 (pp. 99-100). MedWatch. Event date 12 December 2013. Report date 21 December 2013. http://www.fda.gov/AboutFDA/CentersOffices/ OfficeofMedicalProductsandTobacco/AbouttheCenterforTobaccoProducts/ ucm221165.htm (accessed 3 Jun 2015).
94 United States Department of Health and Human Services, Food and Drug Administration, Center for Tobacco Products. CTP FOIA Electronic Reading Room: Special Interest Topics - E-cigarette Adverse Events: Adverse Events 10/5/13 to 3/12/14 (pp. 38-42). Safety Reporting Portal. Problem Start date not reported. Report date 6 Febuary 2014. http://www.fda.gov/AboutFDA/CentersOffices/ OfficeofMedicalProductsandTobacco/AbouttheCenterforTobaccoProducts/ ucm221165.htm (accessed 3 Jun 2015).

95 United States Consumer Product Safety Commission. National Electronic Injury Surveillance System (NEISS): Archived Full NEISS Data by year-2013 NEISS Data. Hospital report of event to CPSC. Unique ID 131011915. Treatment date 27 April 2013. http://www.cpsc.gov/en/Research--Statistics/NEISS-Injury-Data/ (accessed 30 Apr 2015).

96 United States Coast Guard National Response Center. SEQNOS 1114780. Incident date 25 Apr 2015. http://www.nrc.uscg.mil/ (accessed 22 Jun 2015).

97 United States Coast Guard National Response Center. SEQNOS 1115226. Incident date 1 May 2015. http://www.nrc.uscg.mil/ (accessed 22 Jun 2015).

98 Donnelly L, PA. E-cigarettes linked to more than 100 fires. The Telegraph 3 November 2014. http://www.telegraph.co.uk/health/healthnews/11203884/ E-cigarettes-linked-to-more-than-100-fires.html (accessed 13 Nov 2014).

99 Merseyside Fire and Rescue Service, Incident Investigation Team, Community Prevention Dept. E-cigarettes-Merseyside Fire and Rescue Service Current Position, June 2014. http://www.esfrs.org/EasysiteWeb/getresource. axd?AssetID=459\&type=Full\&servicetype=Attachment (accessed $23 \mathrm{Apr}$ 2015).

100 Lacasse $\mathrm{Y}$, Legare $\mathrm{M}$, Maltais F. E-cigarette use in patients receiving home oxygen therapy. Can Respir J 2015;22:83-5.

101 Chesterfield: E-cigarette linked to fatal care home blaze. Derbyshire Times 7 July 2013; Updated 7 November 2013. http://www.derbyshiretimes.co.uk/news/ grassroots/chesterfield-e-cigarette-linked-to-fatal-care-home-blaze-1-6225619 (accessed 5 Aug 2014).

102 Man killed as e-cigarette 'explodes', Merseyside fire service says. BBC News 8 August 2014. http://www.bbc.com/news/uk-england-merseyside-28701515 (accessed 11 Aug 2014).

103 Traynor L. Dad died from heart attack after e-cigarette exploded next to oxygen tank. Mirror 16 October 2014. http://www.mirror.co.uk/news/uk-news/ dad-died-heart-attack-after-4447700 (accessed 16 Apr 2015).

104 Firefighter Engelsman. Fire research report: E-cigarette fire risks and reported incidents. (Doc ID: D15/9073). Fire \& Rescue New South Wales, Australia. 30 Jan 2015. http://www.icao.int/safety/DangerousGoods/DGPWG15/DGPWG.15.IP.004.2. en.App.pdf (accessed 18 Jun 2015).

105 Spencer L, Smith R. E-cigarette explosion hazard-How to avoid dangerous accidents. [transcript-Regional Business News Database, Lexile 1060, Accession Number 102082536]. Good Morning America (ABC) 13 April 2015, 7:42 AM.

106 Heaven Gifts. Product Recalls and Warnings: Evod battery recall. E-cigarette Forum 18 July 2013. http://www.e-cigarette-forum.com/forum/general-e-smokingdiscussion/444286-evod-battery-recall.html (accessed 12 Nov 2013).

107 The Organisation for Economic Co-operation and Development (OECD). Global portal on product recalls. Paris, France. http://globalrecalls.oecd.org/ (accessed 29 Oct 2015).

108 USDHS / FEMA /USFA / National Fire Data Center (NFDC). NFIRSGram: Coding an electronic cigarette fire. 31 October 2014. http://www.usfa.fema.gov/data/nfirs/ support/nfirsgram_electronic_cigarettes.html (accessed 7 May 2015).

109 Government of Canada. Consumer product update: Health Canada warns of fire risk to oxygen therapy patients from electronic cigarettes and other electrical devices. (Identification Number RA42671). 24 November 2014. http://www. healthycanadians.gc.ca/recall-alert-rappel-avis/hc-sc/2014/42671a-eng.php?_ga=1. 231979295.1037671955.1423166373 (accessed 1 Jun 2015).

110 Kurland S. DOT policy on e-cigarettes for the Senate Committee on Commerce, Science and Transportation. 17 June 2010. http://www.dot.gov/sites/dot.gov/files/ docs/PolicyOnECigarettes.pdf (accessed 2 Dec 2014).

111 United States Department of Transportation. Smoking of Electronic Cigarettes on Aircraft: NPRM. Federal Register (76 FR -Vol 76 No. 179, pp. 57008-57012) Docket No. DOT-OST-2011-0044RIN 2105-AE06. 15 September 2011. http:// www.gpo.gov/fdsys/pkg/FR-2011-09-15/pdf/2011-23673.pdf (accessed 20 Feb 2015).

112 United States Department of Transportation, Federal Aviation Administration, Office of the Secretary. Significant Rulemaking Reports by Year: September 2015 Internet Report on DOT Significant Rulemakings-Smoking of Electronic Cigarettes On Commercial Aircraft (RIN 2105-AE06), No. 78. http://www.dot.gov/regulations/ significant-rulemaking-report-archive (accessed 10 Nov 2015).

113 International Air Transportation Authority. Guidance on electronic cigarettes; Effective May, 2015. http://www.iata.org/whatwedo/safety/Documents/ IATA-Guidance-on-Electronic-Cigarettes.pdf (accessed 11 Jun 2015).

114 United Nations, International Civil Aviation Organization. Electronic Bulletin: Dangerous Goods Carried by Passenger and crew_-Incidents related to electronic cigarettes. (EB 2014/074; AN 11/2.1) 10 December 2014. http://www.faa.gov/ about/office_org/headquarters_offices/ash/ash_programs/hazmat/passenger_info/ media/ICAO_ecigarettes_bulletin.pdf (accessed 12 Jun 2015). 
115 United States Department of Transportation, Federal Aviation Administration, Flight Standards Service. Safety Alert for Operators: Fire Risk of Electronic Cigarettes (e-cigarettes) in Checked Baggage (SAFO 15003). 22 January 2015. https://www. faa.gov/other_visit/aviation_industry/airline_operators/airline_safety/safo/all_safos/ media/2015/SAF015003.pdf (accessed 30 Mar 2015).

116 International Air Transportation Authority. Lithium Battery Guidance Document: Transport of Lithium Metal and Lithium Ion Batteries. 15 December 2014. http:/l www.iata.org/whatwedo/cargo/dgr/Documents/lithium-battery-guidance-document2015-en.pdf (accessed 19 Jun 2015).

117 United Nations, International Civil Aviation Organization. Technical instructions for the safe transport of dangerous goods by air, 2015-2016 Edition. 25 May 2015. (Doc 9284-AN/905, Addendum No. 1). http://www.icao.int/safety/ DangerousGoods/AddendumCorrigendum $\% 20$ to $\% 20$ the $\% 20$ Technical $\%$ 20Instructions/Doc\%209284-2015-2016.ADD-1.en.pdf (accessed 19 Jun 2015).

118 United States Department of Health \& Human Services, Food and Drug Administration, Center for Tobacco Products. CTP FOIA Electronic Reading Room: Special Interest Topics—E-cigarette Adverse Events. 20 February 2015, last page update. http://www. fda.gov/AboutFDA/CentersOffices/OfficeofMedicalProductsandTobacco/ AbouttheCenterforTobaccoProducts/ucm221165.htm (accessed 19 May 2015).

119 United States Department of Homeland Security, Federal Emergency Management Administration, United States Fire Administration (USFA). Electronic cigarette fires and explosions. (pp.1 \& 6). Oct 2014. https://www.usfa.fema.gov/downloads/pdf/ publications/electronic_cigarettes.pdf (accessed 13 Mar 2015).

120 Chief Fire Officer's Association. E-cigarette danger: Fire Officers issue safety guidelines after rise in fires caused by e-cigarettes. Huffington Post UK 11 March 2014. http:/l www.huffingtonpost.co.uk/2014/11/03/ecigarette-cause-fires-safety-guidelines_n_ 6092390.html?utm_hp_ref=uk-lifestyle\&ir=UK+Lifestyle (accessed 13 Nov 2014).

121 Pattison K. Fire alert over dangers of e-cigarette chargers. News \& Star 2 April 2015. http://www.newsandstar.co.uk/news/fire-alert-over-dangers-of-e-cigarettechargers-1.1203141 (accessed 21 Apr 2015).

122 United States Department of Transportation, Pipeline and Hazardous Materials Safety Administration. Traveling with lithium batteries. http://phmsa.dot.gov/ safetravel/batteries (accessed 19 Jun 2015).

123 Electronic Cigarette Industry Trade Association. Batteries and mods-a marriage made in heaven, or a disaster waiting to happen: YOU decide! 4 November 2014. http://ecita.org.uk/ecita-news/batteries-and-mods-marriage-made-heaven-ordisaster-waiting-happen-you-decide (accessed 23 Dec 2014).

124 United States Department of Health and Human Services, Food and Drug Administration and National Institutes of Health. Safety Reporting Portal. https:// www.safetyreporting.hhs.gov (accessed 26 Jun 2015).

125 King BA, Patel R, Nguyen $\mathrm{KH}$, et al. Trends in awareness and use of electronic cigarettes among US adults, 2010-2013. Nicotine Tob Res 2015;17:219-27.

126 Regan AK, Promoff G, Dube SR, et al. Electronic nicotine delivery systems: adult use and awareness of the 'e-cigarette' in the USA. Tob Control 2013;22:19-23.

127 Schoenborn CA, Gindi RM. (United States Centers for Disease Control and Prevention, National Center for Health Statistics.) Electronic cigarette use among adults: United States, 2014. NCHS Data Brief, No. 217. Oct 2015. http://www. cdc.gov/nchs/data/databriefs/db217.pdf (accessed 29 Oct 2015).

128 Associated Press. E-cigarettes banned in airline passengers' checked bags. LA Times 26 October 2015. http://www.latimes.com/business/la-fi-ecigarettesairlines-20151026-story.html (accessed 27 Oct 2015).
129 U.S. Consumer Product Safety Commission. CPSC Recalls. https://www.recalls.gov/ cpsc.html (accessed 24 Oct 2015).

130 EN 60065. Audio, video and similar electronic apparatus. Safety requirements.

131 EN 60950. Information technology equipment. Safety. General requirements.

132 EN 61558. Safety of power transformers, power supply units and similar products. General requirements and tests.

133 EN 61558-2. Safety of power transformers, power supply units and combinations thereof. Particular requirements and tests.

134 Buchmann I. Lithium-ion Safety Concerns. 2015. In Cadex Electronics, Inc, Battery University. Vancouver, British Columbia, Canada. http://batteryuniversity.com/learn/ article/lithium_ion_safety_concerns (accessed 14 Oct 2015).

135 Skodacek K. Standards considerations for battery-powered devices. In United States Department of Health and Human Services, Food and Drug Administration, Center for Tobacco Products. Electronic Cigarettes and the Public Health: A Public Workshop. 11 December 2014. http://www. fda.gov/TobaccoProducts/NewsEvents/ucm414814.htm (accessed 20 Oct 2015).

136 United States Department of Health and Human Services, Food and Drug Administration, Center for Devices and Radiological Health. Public Workshop: Battery-Powered Medical Devices_Challenges and Opportunities. 30-31 July 2013. http://www.fda.gov/MedicalDevices/NewsEvents/WorkshopsConferences/ ucm355183.htm (accessed 22 Oct 2015).

137 United States Department of Homeland Security, Federal Emergency Management Administration, United States Fire Administration (USFA) Electronic cigarette fires and explosions (pp.1-11). October 2014. https://www. usfa.fema.gov/downloads/pdf/publications/electronic_cigarettes.pdf (accessed 13 Mar 2015).

138 Brown CJ, Chang JM. Electronic cigarettes: product characterisation and design considerations. Tob Control 2014;23:ii4-10.

139 Branson-Potts $\mathrm{H}$. Woman burned by exploding e-cigarette battery awarded $\$ 1.9$ million. $A B C$ News 1 October 2015. http://abcnews.go.com/health/wirestory/ jury-awards-19m-california-woman-burned-cigarette-34165004 (accessed 1 Oct 2015).

140 Hasto S. The explosive history of lithium-ion batteries. Business Week 28 January 2013. http://web.b.ebscohost.com/ehost/pdfviewer/pdfviewer?sid=818a8dee-15644849-bcff-f44c6220e26e\%40sessionmgr113\&vid=1\&hid=107 (accessed 26 Oct 2015).

141 Hayley T. Consumer agency recalls Chromebook chargers. The Washington Post 18 December 2013. http://search.ebscohost.com/login.aspx?direct=true\&db=bwh\& AN=wapo.4fd35c32-672a-11e3-ae56-22de072140a2\&site=ehost-live\&scope=site (accessed 25 Oct 2015)

142 United States Coast Guard National Response Center. SEQNOS 1130713. Incident date 12 October 2015. http://www.nrc.uscg.mil/ (accessed 20 Oct 2015).

143 ABCNews. Transcript for Credit Card Reader Responsible for Alaska Airlines Emergency Landing. ABC News Internet Ventures 2015. http://abcnews.go.com/ GMA/video/credit-card-reader-responsible-alaska-airlines-emergency-landing34437405 (accessed 14 Oct 2015).

144 Plane makes emergency landing after credit card reader catches fire. NewsChanne/3 12 October 2015. http://www.wwmt.com/news/features/national/stories/ Plane-makes-emergency-landing-after-credit-card-reader-catches-fire-217949.shtml (accessed 14 Oct 2015). 